\title{
J(e)
}

\begin{tabular}{|l||c|c|}
\hline \hline Received 20.12.2020 & & JOTS \\
$5 / 1$ \\
\hline \hline Accepted 02.01.2021 & Review & $2021: 234-239$ \\
\hline \hline Published 10.01.2021 & & \\
\hline
\end{tabular}

\section{Tulu, S. Dede Korkut Oğuznâmesi -Boylar ve Soylamalar- Günümüz Türkçesine Sözlü Çevirisi, Dresden Nüshası ve Günbed-i Kâvus/Türkmensahra Elyazması Esasında, Ankara: Nobel Akademik Yayıncilik, 2020, ss. 392, ISBN: 978-625-406-755-6}

\author{
Mükremin YILDIRIM* \\ S a msun / Turkey \\ E-mail:mkrmnyldrm55@hotmail.com
}

Türk milletinin hayatını, Türk kültürünün sayısız zenginliklerini, Türk’ün yüksek insanî değerini, vasfını ve erdemini yansıtan bir eser olan Dede Korkut Kitabı'nın, XV. yüzyılın sonu ile XVI. yüzyılın başı arasında yazıya geçirildiği düşünülmektedir. Nazım ve nesir türünde olan eserin içinde bulunan hikâyeler, Oğuz Türklerinin IX-XI. yüzyıllar arasındaki yaşama biçimlerini, gelenek ve göreneklerini, değer yargılarını, yaşam mücadelelerini yansıtmaktadır. Eserin Dresden, Vatikan ve Günbed-i Kâvus/Türkmensahra olmak üzere üç nüshası bulunmaktadır. XIX. yüzyılın başlarında Dresden'de bulunmuş olan nüshası, Oğuz boyunun diliyle Dedem Korkut Kitabı anlamına gelen, Kitâb-ı Dedem Korkud alâ Lisân-ı Tâife-i Oğuzân adını taşımaktadır. XX. yüzyılın başlarında Vatikan'da bulunmuş olan nüshası ise Oğuzname hikâyesi, Kazan Bey ve diğerleri" anlamına gelen, "Hikâyet-i Oğuzname, Kazan Beğ ve Gayrı adını taşımaktadır. Dede Korkut Kitabı'nın Dresden nüshasında bir giriş bölümü ile 12 hikâye bulunmaktadır. Vatikan nüshasında ise Dresden nüshasında bulunan giriş ve hikâyelerden farklı olmayan 6 hikâye bulunmaktadır. Son yıllarda ise Dede Korkut Kitabı'nın başka bir nüshası

ORCID ID: 0000-0001-7780-6975. 


\section{0}

bulunmuştur. Dede Korkut hikâyelerinin üçüncü nüshası ise Türkiye'de M. Ekici ve Y. Azmun tarafından yayımlanmıştır.

Dede Korkut Kitabı hiç şüphesiz, Türklük Bilimi için eşsiz bir eserdir. Türk edebiyatının en gözde eserlerinin başında gelir dersek, yanlış bir söylemde bulunmuş olmayız. Öyle ki, Türk edebiyatı tarihinin büyük âlimi F. Köprülü, bu büyük eserin önemini anlatmak için "Bütün Türk edebiyatın terazinin bir gözüne, Dede Korkut'u öbür gözüne koysanız, yine Dede Korkut ağır basar" demiștir. Dede Korkut Kitabı, millî destan olmasının yanı sıra müellifinin millet olması yönünden de oldukça önemlidir. Bu bağlamda, milleti millet yapan en önemli değerlerden biri olan kültürü yansıtmaktadır. Kültür ile birlikte tabiatın ön planda olması, hızlı ve coşkun bir zaman içinde olayların geçmesi, Türklerin hayat tarzı hakkında bize bilgi vermektedir. Dede Korkut Kitabı'nın, bünyesinde barındırdığı birçok vasfının yanında en büyük vasfı, dil vasfıdır. Oğuz dilinin en güzel, açık, yalın ve aynı zamanda coşkun bir üslup ile yazılmış en kutsal kitabı durumundadır. Bu özellikleri açısından bakıldığında, bu eser üzerine bilim insanlarımız tarafından çalışmalar yapılması, bir hayli kaçınılmaz bir durumdur.

Dede Korkut Kitabı'nın üzerine birçok çalışma yapılmıştır. Vatikan nüshasının ilim âlemince 1950 yılından sonra tanınmasından dolayı, yapılan çalışmaların daha çok Dresden nüshası üzerine yoğunlaştığı görülmektedir. Eserin Dresden nüshas1, Dresden Kral Kütüphanesinde ilk kez H.O. Fleischer tarafından bulunmuştur. İlim âlemine tanıtımı ise H. F. von Diez tarafından yapılmıştır. Vatikan nüshası ise Ettore Rossi tarafından Vatikan Türkçe yazmalar arasında bulunmuştur. Rossi, Vatikan kitaplığında bulduğu bu eseri bilim dünyasına tanıttıktan iki yıl sonra (1952) Oğuznâmenin İtalyanca çevirisini, tıpkıbasımını ve incelemesini bir kitapta toplamıştır. Rossi, altı hikâyeyi içine alan Vatikan nüshasının, Dresden nüshasına göre çok düzgün yazıldığını ve harekeli olduğundan dolayı Dresden nüshasının anlaşılmasında yarar sağlayabileceğini belirtmiştir.

Türkiye'de ise Kilisli Rıfat tarafından neşri yapıldıktan sonra Dede Korkut Kitabı üzerine çalışmalar başlamıştır. İlk neşirden sonra Orhan Şaik Gökyay Dede Korkut Kitabı'nı düzeltmeler ve incelemeler yaparak 1938'de yeni Türk alfabesiyle yayımlamıştır. 1958 yılında ise Muharrem Ergin tarafından Dede Korkut Kitabı'nın ilk bilimsel metin yayını yapılmıştır. Eserin dili açısından Ergin, Rossi'den farklı 


\section{ग(๑)}

düşünmektedir. Yayımladığı eserde, Vatikan nüshasının Dresden nüshasına göre çok kötü durumda olduğunu, iki nüshanın da XVI. asırdan öncesine ait olamayacağını söylemektedir. Ergin nüshalarda bulunan dil farkını saha ayrılığına bağlamaktadır. Kelime başındaki /b/ > /m/, /t/ > /d/ değişimi, ilk hecedeki /e/ ve /i/ meselesi, /k/, /h/ ve /g்/ meselesi ve Vatikan nüshasında, Dresden'deki $\{$-gAç\} gerundiumu yerine $\{-$ IcAk\} gerundiumunun kullanılmasını örnek olarak göstermektedir. Bütün bu özellikleri göz önünde bulundurarak Dresden nüshasının XVI. yüzyılın ilk yarısında, Vatikan nüshasının ise XVI. yüzyılın ikinci yarısında istinsah edildiğini tahmin etmektedir. Son yıllarda ise S. Tezcan ve $\mathrm{H}$. Boeschoten tarafından Dede Korkut Oğuznameleri adlı eser yayımlanmıştır. Tezcan ve Boeschoten, bu eserin iki farklı nüshasının olmadığını dolayısıyla birinin iyi birinin kötü olma durumunun da olmadığını ileri sürmektedir. Bir diğer yandan yazarlar Dede Korkut Oğuznameleri'nin dilinin Doğu Anadolu ağız özellikleriyle karışmış Eski Anadolu Türkçesi olduğunu savunmuşlardır. Yukarıda da görüldüğü üzere, Dede Korkut Kitabı üzerine yapılan çalışmalarda birçok yönden farklılık görülmektedir. Burada tanıtacağımız eser ise S. Tulu'nun bilim dünyasına kazandırdığı eserdir.

Tulu'nun eseri yazar hakkında, önsöz, kısaltmalar ve işaretler, bibliyografya, I. bölüm, II. bölüm, sözlük ve ekler bölümlerinden oluşmaktadır.

Çalışmada yazar hakkında bilgi verildikten sonra önsöz bölümüne geçilmiştir. Önsöz bölümünde eserin tarihî önemi hakkında bilgi verilmiştir. Bu bölümde Dede Korkut Kitabı'nın üzerine yapılan filolojik çalışmalar ve diğer yapılan çalışmalardaki eksikliklerin giderilmesi, hataların onarılması ve yeniden okuma önerilerinin eserde mevcut olduğundan bahsedilmiştir. Yazar, önsöz bölümünde, bu çalışmanın önceki yapılan çalışmalardan farklı olarak eski çalışmalar ve yorumların dikkate alınarak karşılaştırmalı olarak yapıldığını söylemiştir. Önsöz bölümünden sonra yazar eserdeki kısaltmalar ve işaretler ile bibliyografya bölümlerine yer vermiştir. Bibliyografta bölümünde, çalışmada toplam 100 kaynak adı gösterilmiştir.

Eserin birinci giriş bölümünde (s. 1-3), Dede Korkut Kitabı'nın tarihi, yazıldığı tür ve içeriği hakkında bilgi verilmiştir. Bu bölümde Korkut ata hakkında bilgi verilmiş ve aynı zamanda eser üzerine yapılan çalışmalara değinilmiştir. Bu 


\section{ग(৫)}

çalışmalarda eksiklik olduğu belirtilerek Tezcan ve Boeschoten'in iki nüshayı ayrı ayrı yayımlayarak onardığı söylenmiştir.

Çeviride dikkate alınacak notlar bölümünde (s. 3-4), yapılan çalışmanın Dresden, Vatikan, Günbed-i Kāvus yazmalarının karşılaştırılarak ortaya konduğu belirtilmiştir. Çeviri yapılırken yazmanın orijinal dilinden çok fazla uzaklaşmadan yazıcının üslubunun korunmaya çalışıldığı da söylenmiştir.

Dede Korkut metinlerinin dili ve yazıldığı dönem (s. 4-8) kısmında, Dede Korkut metinlerinde birçok karışık yazım/imlâ sorunlarıyla karşılaşıldığı ve metinlerin okunmasını zorlaştırdığı belirtilmiştir. Eserin yazıldığı dönem hakkında çeşitli görüşlere yer verilmiştir. Yazara göre eser, Uygur harfli yazılmış bir Oğuznâme'den Akkoyunlular döneminde, Azerbaycan ve Osmanlı sahasında yazıcıların ağız özellikleriyle yeniden yazılmıştır. Yazar, yeni ortaya çıkan Günbed-i Kâvus (Gün.) elyazmasında buna ait ipuçlarının varlığından bahsetmiştir.

Çeviri yöntemi kısmında (s. 8-12), bağlama uymayan sık kullanılan deyimler olduğu gibi bırakıldığı ve yapılan hatalar çevirilerde düzeltildiği belirtilmiştir. Diğerlerinden farklılık gösteren düzeltmeler, ayrı bölümlerde ayrıca gösterilmiştir. Yazmada okuma hatalarından kaynaklanan hataların tespit edildiği belirtilip bunun üzerine örnekler gösterilmiştir.

Yazar, metinde iki şekilde yazılmış ḳamın ve kanın kelimelerinin üzerinde durmuştur (s. 13-14). Kelimelerin geçtiği satırları vererek beş yerde kamın, iki yerde ise kanın okunduğunu tespit etmiştir. Bunun yanında bu kelimeler üzerine yapılan çeşitli okumalara yer vermiştir.

Eserde ikilemeler ve ikili kullanımlar (s. 14-18) kısmında, birçok ikileme ve ikili kullanım verilmiştir. Yazar bu kullanımlardan hareketle metnin yazıldığ dönemi tespit etmeye çalışmıştır. Yapılan araştırmalardan hareketle yazar, metnin Doğu Türkçesi, Azerbaycan Türkçesi ve Osmanlı Türkçesi olarak üç tabakadan oluştuğunu ileri sürmektedir. Bu bölümde dikkat çeken ikilemeler yazar tarafından alfabetik sırayla verilmiştir.

Yazar, arkaik ögeler (s. 19-21) kısmında birçok arkaik ögelere yer vermiştir. Fakat bize göre bu sözcüklerin bazıları tartışmalıdır. Arkaik kelimesinin Türkçe karşıllı̆̆ eskicildir. Bu sözcükler geçmişte kullanılan, günümüzde ya da 


\section{J(৫)}

bulunduğu dönemde kullanımdan düşmüş yahut farklı biçimde yazılı eserlerde ya da ağızlarda yer alan sözdizimsel birimlerdir.

“Arkaiklik (eskicilik), bir dilde Eski Türkçeyle karşılaştırıldığında öteki Türk dillerinde bulunmayan ses ve yapı özelliklerinin yanı sıra sözlüksel biçimlerin de Eski Türkçeye benzer biçimde yaşaması, kullanılmasıdır" (Ölmez, 2003: 136). Bu durumda bir sözcüğün arkaik sayılabilmesi için günümüzde ya da bulunduğu dönemde kullanımdan düşmüş olması gerekmektedir. Korkmaz'a göre eskicil tanımı şu şekildedir: "Eskilik: Eskiden kalma; yazı ve konuşma dilinde artık kullanıştan düşmüş olan, dilin daha eski veya tarihî devrelerine ait kelime, deyim ve şekiller" (1992: 55). Görüldüğ̈̈ üzere yazı ve konuşma dilinde artık kullanımdan düşmüş olan şeklinde tanımlanmaktadır. Fakat bunun için bir ölçüt belirlemek gerekmektedir. Yazarın arkaik olarak verdiği sözcüklere bakıldığında bunların günümüzde ve eserin yazıldığı dönemde hâlâ kullanımda olduğu görülmektedir. Fakat bize göre burada yapılan hata, arkaik unsur belirlenirken bir ölçüt koyulmamasıdır. Burada arkaik olduğu söylenilen sözcükler belirlenirken bir ölçüt koyulması gerekir. Yazarın aldığı ata 'baba', kız- 'öfkelenmek', çağır- 'davet etmek', yavuz 'fena', yazı 'ova, çöl' gibi sözcükler günümüzde Türkiye Türkçesi ölçünlü dilinde ve ağızlarda yaygın bir şekilde yaşamaktadır. Bazı sözcüklerin ise Çağdaş Türk lehçelerinde yaygın bir şekilde kullanıldığı görülmektedir. Bu sözcükler arkaik ise o dönemde ve günümüzde kullanılmaması gerekmez mi?

Burada özellikle bir ölçüt koyulması gerekir.

Gülsevin,

“Eski Türkçedeki agu 'zehir' kelimesi yerine daha sonra Anadolu Türkçesinde de Arapça kökenli zehir kelimesi yaygınlaşmıştır. Bugün edebî Türkiye Türkçesinde zehir kelimesi kullanılır. Türkiye Türkçesinin bazı ağızlarında ise hâlâ eski ağı/ağu kelimesi yaşamaktadır. Akhisar-Manisa, Bandırma-Balıkesir vs. ağızlarındaki ağu kelimesi o ağızlar söz konusu olduğunda elbette arkaik değildir. Çünkü ağu kelimesi onlarda doğal olarak yaşamaktadır (tıpkı edebî dildeki baş, ben kelimeleri gibi). Edebî dili oluşturan İstanbul ağzı ile karşılaştırdığımızda, bazı ağızlarda görülen ağu şekli İstanbul ağzına göre arkaik bir unsuru devam ettirmiş olmaktadır” (2015: 4)

şeklinde bu durumu açıklamaktadır. Bu düşünceden hareketle yazarın arkaik olarak verdiği sözcükler, eserin yazıldığı dönemde ve sonrasında kullanımdan düşmüş olması gerekmektedir. Ancak verilen sözcükler günümüze 


\section{J(ङ)}

kadar gelmiş ve yaygın şekilde kullanılmıştır. Yani eserde arkaik unsurlar belirlenirken bu ölçütün gözden kaçtığı görülmektedir. Sadece kendinden önceki dönemlerde kullanılan bu sözcükleri arkaik olarak ele almak doğru bir yaklaşım değildir.

Tasvîri/yardımcı fiillerin kullanımı (s. 21-23) kısmında, yazar, bu kullanımların, metin içerisinde güçlük yarattığını ve günümüzde kullanımdan düştüğünü söylemiştir. Serbest çevirilerde bu kullanımların metnin daha iyi anlaşılmasına yardımcı olacağı belirtilmiştir. Bunların yanında yazar 1. bölümde 12 boyun (s. 23-254) orijinal ve transkripsiyonu vermiştir.

Yazar, 2. bölümde Günbed-i Kāvus (Gün.) yazmasının içeriği ve dilbilgisi özellikleri hakkında bilgi vermiştir (s. 255-259). Bu yazmanın, İran/Azerbaycan sahasında XVI. yüzyılın ikinci yarısında yazıya geçirildiği ve XVIII. yüzyılın ikinci yarısında Kaçar hâkimiyetindeki İran/Azerbaycan sahasında yazıya geçirildiği söylenmiştir. Aynı zamanda yazar, bu yazmayla birlikte Dresden ve Vatikan nüshalarının yanında üçüncü bir dil katmanının bulunduğunu ileri sürmektedir. $\mathrm{Bu}$ yazmanın, eldeki nüshalardan farklı bilgiler içermekle birlikte mevcut yazmaların daha iyi anlaşılması konusunda yardımcı olabileceği belirtilmiştir. Bu bağlamda yazar bu eseri neşrederken Dresden ve Vatikan nüshalarını daha iyi çözebilmek için bu yazmadan yararlanmıştır. İkinci metin çevirisi, boylar ve soylamalar verildikten sonra yazar, kendi okuma, onarma ve çevirilerine yer vermiştir.

Yazar, kendi okuma, onarma ve çeviriler (s. 327-341) kısmından sonra sözlük (s. 343-365) bölümüne yer vermiştir. Son ekler (s. 367-370) bölümünde ise Dede Korkut Kitabı'nın Dresden nüshası kapak sayfası, giriş sayfası ve Dede Korkut Kitabı Günbed-i Kâvus/Türkmensahra elyazmasının kapak resmi ve sayfa örneği verilmiştir.

\section{Kaynakça}

Gülsevin, G. (2015). Arkaik-Periferik Kavramı ve Bu Kavramın Tarihî Batı Rumeli Türkçesi Ağızlarının Tespitindeki Önem. The Journal of Academic Social Science Studies. 3 (32), 1-12.

Korkmaz, Z. (1992). Gramer Terimleri Sözlüğü. Türk Dil Kurumu Yayınları.

Ölmez, M. (2003). Çağataycadaki Eskicil Öğeler Üzerine. In Ata, A. \& Ölmez, M. (Eds.), Dil ve Edebiyat Araştırmaları Sempozyumu 2003: Mustafa Canpolat Armağanı (pp. 135-142). Sanat Kitabevi. 